\title{
List of Contributors
}

\author{
Manuel Bamert \\ ETH Zurich, Clausiusstrasse 59, 8092 Zürich, Switzerland, \\ mbamert@ethz.ch
}

Doctoral Candidate at the Chair for Literary and Cultural Studies at ETH Zurich. Areas of research: analysis and digitisation of private libraries and reading notes, materiality and mediality of literature, Gender and Queer Studies, works of Thomas Mann and Max Frisch. Publications: Gelesenes Gedrucktes. Textzentrierte Erklärungsansätze zur Entstehung von Lesespuren (2020); Homo Stiller: Männliche Identitäten und Sexualitäten in Max Frischs ,Stiller` (2016).

\section{Peter Boot}

Huygens Institute for the History of the Netherlands (Royal Netherlands Academy of Arts and Sciences), Postbus 10855, 1001 EW Amsterdam, Netherlands, peter.boot@huygens.knaw.nl

Senior Researcher at the Huygens Institute for the History of the Netherlands in Amsterdam. Areas of research: Digital Literary Studies, scholarly editing, online book discussion, scholarly annotation, text analysis. Publications (selection): Mesotext. Digitised Emblems, Modelled Annotations and Humanities Scholarship (2009); The Digital Edition 2.0 and the Digital Library: Services, not Resources (co-authored, 2011); The desirability of a corpus of online book responses (2013); $A$ FRBROO-based annotation ontology for digital editing (co-authored, 2018); Editing social media: the case of online book discussion (2019); Exploring the features of naturalist prose using LIWC in Nederlab (co-authored, 2019).

\section{Tamara Drummond}

University of Bremen, Faculty 10: Linguistics and Literary Studies, Universitäts-Boulevard 13, 28359 Bremen, Germany, tamara.drummond@uni-bremen.de

Doctoral Candidate in Linguistics at the University of Bremen. Areas of research interest: multimodality, discourse and text analysis, media analysis, semiotics.

\section{Walter Fanta}

Robert-Musil-Institut für Literaturforschung/Kärntner Literaturarchiv, Bahnhofstraße 50, 9020 Klagenfurt, Austria,

\section{Walter.Fanta@aau.at}

Senior Scientist at the Robert-Musil-Instititut für Literaturforschung/Kärntner Literaturarchiv, University of Klagenfurt. Areas of research: digital editions, critique génétique, writing process, 
modern Austrian literature. Publications (selection): Die Entstehungsgeschichte des, Mann ohne Eigenschaften “ von Robert Musil (2000); Krieg. Wahn. Sex. Liebe. Das Finale des Romans ,Der Mann ohne Eigenschaften' von Robert Musil (2015); Robert Musil: Gesamtausgabe in 12 Bänden (edition, 2016-2021).

\author{
Lina Franken \\ Universität Hamburg, Edmund-Siemers-Allee 1 West, 20146 Hamburg, Germany, \\ lina.franken@uni-hamburg.de
}

Postdoctoral Researcher in Cultural Anthropology and Coordinator of the research project 'Automated Modelling of hermeneutic Processes (hermA)'. Areas of research: digital qualitative methods and digital cultures, school cultures and cultural education, working and food cultures. Publications (selection): Digitales wissenschaftliches Arbeiten? Zum methodischen Wandel qualitativer Forschung im Diskurs. In: Berliner Blätter - Ethnographische und ethnologische Beiträge (2020); Unterrichten als Beruf. Akteure, Praxen und Ordnungen in der schulischen Wissensvermittlung (2017).

\title{
Joseph S. Freedman
}

Alabama State University, 915 South Jackson Street, Montgomery, Alabama 36104, USA, joseph-freedman@usa.net, jfreedman@alasu.edu

Professor of History with a primary focus on academic (scholastic) philosophy during the 16th, 17th, and early 18th centuries (primarily in Central Europe.). An additional focus on archival theory in Central Europe during the 16th, 17th, and 18th centuries. Publications (selected): European Academic Philosophy in the Late Sixteenth and Early Seventeenth Centuries: The Life, Significance, and Philosophy of Clemens Timpler, 1563/64-1624, 2 vols (1988); Philosophy and the Arts in Central Europe, 1500-1700: Teaching and Texts at European Schools and Universities. (1999); Die Zeit um 1670: Eine Wende in der europäischen Geschichte und Kultur? (ed., 2016); Some Indirect Constraints to Academic Freedom in the 'Republic of Letters' during the 17th, the Late 20th, and the Early 21st Centuries. (2018); All You Need is Love? Emotion (Gefühl) and Norm in the Synopsis (Tabulae synopticae: 1728) of the Philosophical Writings of Johann Franz Buddeus (1667-1729). (2018).

\section{Evelyn Gius}

Technische Universität Darmstadt, Dolivostraße 15, 64293 Darmstadt, Germany, evelyn.gius@tu-darmstadt.de

Professor for Digital Philology and Modern German Literature at the Institute for Language and Literature at Technical University of Darmstadt. Areas of research: annotation, segmentation of narrative texts, digital methodology and Computational Literary Studies. Publications (selection): Erzählen über Konflikte. Ein Beitrag zur digitalen Narratologie (2015); The Hermeneutic Profit of Annotation. On preventing and fostering disagreement in literary text analysis (co-authored, 2017); 
A Shared Task for the Digital Humanities Chapter 2: Evaluating Annotation Guidelines (co-authored, 2019).

\author{
Maria Hinzmann \\ Universität Trier, FB II/Trier Center for Digital Humanities, Universitätsring 15, 54296 Trier, \\ Germany, \\ hinzmannm@uni-trier.de
}

Postdoctoral Researcher at the Trier Center for Digital Humanities in the project, Mining and Modeling Text' (coordination/data modeling) at the University of Trier. Areas of research: Digital Humanities, Digital Literary Studies, Linked Open Data, Inter-/Transciplinarity, Rhetoric/ Topics. Publications (selection): Topik zwischen Modellierung und Operationalisierung. Topoi deutschsprachiger Indienreiseberichte um 1900 (forthcoming).

\author{
Jan Horstmann \\ Forschungsverbund Marbach Weimar Wolfenbüttel, Burgplatz 4, 99423 Weimar, Germany, \\ jan.horstmann@mww-forschung.de
}

Head of the Digital Laboratory in the Marbach Weimar Wolfenbüttel Research Association (MWW). Areas of research: Digital Humanities with a special focus on digital text analysis, methods of Literary Studies, (transmedial) narratology, performance and theater, German literature from the 18th century until the present. Publications (selection): Theaternarratologie. Ein erzähltheoretisches Analyseverfahren für Theaterinszenierungen (2018); Narrative representation and fictionality in performative media (2018); Alte Fragen, neue Methoden - Philologische und digitale Verfahren im Dialog (2019); Zeitraum und Raumzeit: Dimensionen zeitlicher und räumlicher Narration im Theater (2019).

\title{
Gertraud Koch \\ Universität Hamburg, Edmund-Siemers-Allee 1 West, 20146 Hamburg, Germany, gertraud.koch@uni-hamburg.de
}

Professor of Cultural Anthropology and Spokesperson of the research project 'Automated Modelling of hermeneutic Processes (hermA)' and Coordinator of the Horizon 2020 Innovative Training Network POEM on participatory memory practices in digital media ecologies; https://www.poemhorizon.eu/. Areas of research: Digital Anthropology and Ethnography, Science and Technology Studies, Heritage Studies and Diversity Studies. Publications (selection): Source criticism of data platform logics on the internet. In: Historical Social Research. Special Issue: Challenges for Big Data Analysis. Data Quality and Data Analysis of Analogous and Digital Mass Data (co-authored, forthcoming); Digitisation. Theories and Concepts for Empirical Cultural Research (editor, 2017). 


\author{
Marijn Koolen \\ Humanities Cluster (Royal Netherlands Academy of Arts and Sciences), Oudezijds Achterburgwal \\ 185, 1012 DK Amsterdam, Netherlands, \\ marijn.koolen@di.huc.knaw.nl
}

Researcher and Software Engineer at the Department of Digital Infrastructure of the KNAW Humanities Cluster. Areas of research: scholarly annotation, online book discussion, text mining in historical corpora, information retrieval, recommender systems. Publications (selection): $A$ Workflow Analysis Perspective to Scholarly Research Tasks (co-authored, 2020); Data Scopes for Digital History Research (co-authored, 2019); A FRBROO-based annotation ontology for digital editing (co-authored, 2018); A Process model of Scholarly Media Annotation (co-authored, 2017); Audiovisual media annotation using Qualitative Data Analysis Software: a comparative analysis (co-authored, 2017).

\title{
Sarah Lang
}

University of Graz, Zentrum für Informationsmodellierung, Elisabethstraße 59/III, $8010 \mathrm{Graz}$, Austria, sarah.lang@uni-graz.at

Doctoral Candidate in the Digital Humanities at Zentrum für Informationsmodellierung of University of Graz. Areas of research: Digital Classics, Digital Humanities applications for alchemical print literature and early modern history of science. Publications (selection): Review of, Perseus Digital Library ' (2018); Ein religionswissenschaftlicher Kommentar zu den Arcana Arcanissima und der Mythoalchemie des alchemo-hermetischen latrochemikers Michael Maier (1568-1622) (2018).

\section{Felix Lange}

Max-Planck-Institut für Wissenschaftsgeschichte, Forschungsprogramm „Geschichte der Max-Planck-Gesellschaft“, -IT und Digital Humanities-, Boltzmannstr. 22, 14195 Berlin, Germany, flange@mpiwg-berlin.mpg.de, fxlange@posteo.net

DH-Research Software Engineer (until 2020) with a focus on the historical sciences. Areas of expertise: full-stack software development and software architecture, data management, Natural Language Processing. Publications (Selection): Semantische angereicherte 3D-Messdaten von Kirchenräumen als Quellen für die geisteswissenschaftliche Forschung, In: ZfDH 1 (m. M. Unold, 2015).

\section{Christian Lück \\ Fernuniversität in Hagen, Universitätsstr. 33, 58084 Hagen, Germany, christian.lueck@fernuni-hagen.de}

Postdoctoral Researcher for Modern German Literature, research assistant in "Das Beispiel im Wissen der Ästhetik (1750-1850)”, funded by DFG. Areas of research: literature, media and law; history of german philology since 1800; Digital Humanities. Publications (selection): Delinquenz 
lernen. Zum KI-Verfahren case-based reasoning und seiner Anwendung im Recht (2019). Recent books and periodicals (co-editor): Konformieren. Festschrift für Michael Niehaus (2019); z.B. Zeitschrift zum Beispiel (since 2018).

\section{Willard McCarty \\ www.mccarty.org.uk, \\ willard.mccarty@mccarty.org.uk}

Professor em., Humanities Computing, King's College London. Areas of research: the history, philosophy and anthropology of computing in and of the human sciences. Publications: see www. mccarty.org.uk; note also As perceived, not as known: Digital enquiry and the art of intelligence, In: Science in the Forest, Science in the Past II, Interdisciplinary Science Reviews (forthcoming 2021).

\section{Julia Nantke}

Universität Hamburg, Überseering 35, 22297 Hamburg, Germany,

julia.nantke@uni-hamburg.de

Juniorprofessor for Modern German Literature with a special focus on Digital Humanities and written artifacts at the Universität Hamburg. Areas of research: digital literature and Digital Literary Studies, materiality and mediality of literature, scholarly editing, literary theory, literature and art of the Avantgardes. Publications (selection): Ordnungsmuster im Werk von Kurt Schwitters. Zwischen Transgression und Regelhaftigkeit (2017); Multiple Autorschaft als digitales Paradigma und dessen Auswirkungen auf den Werkbegriff (2018); New Practices = New Conditions? Interrelations of Practical Approaches, Methodologies ans Theoretical Concepts in Digital Literary Studies (2019).

\section{Georg Rehm}

DFKI GmbH, Alt-Moabit 91c, 10559 Berlin, Germany, georg.rehm@dfki.de

Principal Researcher in the DFKI Speech and Language Technology department. Head of the German/Austrian Chapter of the World Wide Web Consortium (W3C). Areas of research: text and web content curation technology, language technology platforms and infrastructures, text analytics, multilingual Europe. Projects (selection): European Language Grid (ELG), QURATOR (Curation Technologies). Publications (selection): Proceedings of the 1st International Workshop on Language Technology Platforms (IWLTP 2020); Towards an Interoperable Ecosystem of Al and LT Platforms: A Roadmap for the Implementation of Different Levels of Interoperability (2020); A Workflow Manager for Complex NLP and Content Curation Workflows (2020); European Language Grid: An Overview (2020); The European Language Technology Landscape in 2020: LanguageCentric and Human-Centric Al for Cross-Cultural Communication in Multilingual Europe (2020). 


\author{
Nils Reiter \\ Universität Stuttgart, Pfaffenwaldring 5b, 70569 Stuttgart, Germany, \\ nils.reiter@ims.uni-stuttgart.de
}

Postdoctoral Researcher at the Institute for Natural Language Processing, Stuttgart University. Areas of research: Semantics, Computational Literary Studies, Digital Humanities. Publications (selection): Reflektierte Algorithmische Textanalyse (co-edited, 2020); A Shared Task for the Digital Humanities Chapter 1: Introduction to Annotation, Narrative Levels and Shared Tasks (co-authored, 2019); Discovering Structural Similarities in Narrative Texts using Event Alignment Algorithms (2014).

\author{
Frederik Schlupkothen \\ University of Wuppertal, Rainer-Gruenter-Straße 21, 42119 Wuppertal, Germany, \\ schlupkothen@uni-wuppertal.de
}

Postdoctoral Researcher in Print and Media Technology in the field of Electronic Media and Head of the Document and Scholarly Editing Lab at the University of Wuppertal. Areas of research: document theory, multi-channel publishing, markup languages. Publications (selection): Interoperability Between Medical Image Archives and Consumer Devices Through Web Services (2012); HTML to LaTeX transformation (2014); A Genre-aware Document Model for Multichannel Publishing Workflows (2016); Multistructured Document Description based on XLink (2017).

\author{
Karl-Heinrich Schmidt \\ University of Wuppertal, Rainer-Gruenter-Straße 21, 42119 Wuppertal, Germany, \\ karl-heinrich.schmidt@dmt.uni-wuppertal.de
}

Since 2001 Professor for Electronic Media at the University of Wuppertal. Areas of research: multimedia documents with regard to creation (edition and publication) and usage, document theory and empirical document analysis for diverse document types. Publications (monographs): Texte und Bilder in maschinellen Modellbildungen (1992); Wissensmedien für kognitive Agenten (1999); Multimodal Film Analysis: How Films Mean (co-authored, 2011).

\title{
Ruggero Sciuto
}

The Voltaire Foundation and Wolfson College, University of Oxford, 99, Banbury Road, OX2 6JX, Oxford, U.K., ruggero.sciuto@voltaire.ox.ac.uk

Junior Research Fellow in French and Digital Editing, specialising in eighteenth-century literature and philosophy, and leading a Mellon-funded project to create a born-digital critical edition of the complete works of Paul-Henri Thiry d'Holbach. Areas of research: French Enlightenment, intellectual history, history of ideas, atheism, materialism, digital critical editing, history of diplomacy. Publications (selection): Diderot and d'Holbach: A Theory of Determinism (forthcoming, 2022); born-digital critical edition of d'Holbach's Lettres à Eugénie, ou Préservatif contre les préjugés 
(forthcoming 2020); Voltaire et Johann Baptist Anton von Pergen (2018); The Correspondence of André Morellet: Seven Unpublished Letters to Luigi Lorenzi (2016).

\section{Janina Wildfeuer}

University of Groningen, Faculty of Arts, Department of Communication and Information Studies, Oude Kijk in't Jatstraat 26, 9712 EK Groningen, Netherlands,

j.wildfeuer@rug.nl

Assistant Professor in Language and Social Interaction with a special focus on multimodality at the University of Groningen. Areas of research: multimodality, semiotics, discourse and text analysis, media analysis. Publications (selection): Multimodality: Disciplinary Thoughts and the Challenge of Diversity (co-edited, 2019); Comicanalyse: Eine Einführung (co-authored, 2019); Multimodality: Foundations, Research, Analysis. A Problem-Oriented Introduction (co-authored, 2017).

\section{Marcus Willand}

Germanistisches Seminar, Universität Heidelberg, Hauptstr. 207-209, 69117 Heidelberg, Germany,

\section{Marcus.Willand@gs.uni-heidelberg.de}

Postdoctoral Researcher at the German Seminar, University of Heidelberg. Areas of research: (digital) drama analysis, drama history, literary theory and (digital) reception studies. Publications (selection): Lesermodelle und Lesertheorien (Diss., 2014/2017); Theorien und Praktiken der Autorschaft (co-edited, 2014, 2017); A Shared Task for the Digital Humanities Chapter 3: Description of Submitted Guidelines and Final Evaluation Results (co-authored, 2019).

\section{Heike Zinsmeister}

Universität Hamburg, Überseering 35, 22297 Hamburg, Germany, heike.zinsmeister@uni-hamburg.de

Professor for Linguistics and Spokesperson of the research project 'Automated Modelling of hermeneutic Processes (hermA)'. Areas of research: Corpus Linguistics, Computational Linguistics, Pragmatics. Publications (selection): Korpuslinguistik (co-authored, 2019); annDH - Annotation in Digital Humanities (co-edited, 2018); Anaphora with Non-nominal Antecedents in Computational Linguistics: A Survey (co-authored, 2018). 
